\title{
Kedudukan Mediasi Penal Dalam Sistem Peradilan Di Indonesia
}

\section{Beja Suryo Hadi Purnomo ${ }^{1}$}

\author{
${ }^{1}$ Fakultas Hukum, Universitas Gadjah Mada, Yogyakarta, Indonesia
}

\section{A R T I C L E I N F O}

Article history:

Received 31 Oktober 2018

Accepted 30 November 2018

Available online 31

Desember 2018

\section{Kata Kunci:}

Mediasi penal; Sistem peradilan; Kepastian

hukum

Keywords:

Reasoning mediation,

Judicial system, Legal

certainty

\begin{abstract}
A B S T R A K
Mediasi penal dapat dilakukan jika para pihak yang terlibat dalam perudingan saling menyadari dan menghargai terhadap hasil yang diperoleh dalam mediasi penal, karena prinsip yang terpenting dalam mediasi penal adanya pengakuan kesalahan dan pemberian maaf oleh pihak yang dirugikan akibat tindak pidana untuk mencapai penyelesaian berupa win-win solution. Dalam sistem peradilan pidana baik pada tingkat penyidikan, penuntutan maupun sidang pengadilan dimungkinkan adanya mediasi penal dengan berpegang pada prisip kepastian hukum, kemanfaatan hukum dan keadilan hukum.
\end{abstract}

A B S T R A C T

Penal mediation can be carried out if the parties involved in the negotiation are aware of and respectful of the results obtained in the reasoning of mediation, because the most important principle in the mediation of reason is the recognition of mistakes and forgiveness by those who are harmed due to criminal actions to achieve a win-win settlement. solution. In the criminal justice system, both at the level of investigation, prosecution and court session, it is possible to have reasoning mediation by adhering to the principles of legal certainty, legal benefit and legal justice.

Copyright (c) Universitas Pendidikan Ganesha. All rights reserved.

\footnotetext{
* Corresponding author.

E-mail addresses: bejosuryohp@yahoo.com
} 


\section{Pendahuluan}

Hukum sejatinya dibentuk dan diberlakukan sebagai sarana untuk memberikan perlindungan kepada setiap orang secara berkeadilan. Hukum Indonesia, sebagaimana tersirat di dalam Pembukaan Undang-Undang Dasar 1945, merupakan instrumen untuk mendukung terselenggaranya fungsi dan tugas negara untuk melindungi segenap bangsa dan tumpah darah Indonesia, memajukan kesejahteraan umum, mencerdaskan kehidupan bangsa, menciptakan perdamaian serta mewujudkan keadilan sosial bagi seluruh rakyat Indonesia.

Hukum pidana Indonesia sebagai bidang spesifik dalam sistem hukum nasional berfungsi memberikan perlindungan terhadap hak dan kepentingan individu, masyarakat, bangsa dan negara yang diwakili oleh pemerintah, termasuk hak dan kepentingan pelaku tindak pidana dan korban tindak pidana. Pengakuan dalam level normatif konstitusional dan konseptual ini tentulah tidak memiliki arti apa-apa mana- kala tidak dapat diwujudkan, yakni bilamana tidak didukung dengan pengaturan yang baik dalam peraturan perundang-undangan serta komitmen penuh dari para pihak yang bertanggungjawab, yakni warga masyarakat dan aparat penegak hukum. Warga masyarakat merupakan subjek hak dan kewajiban yang seyogyanya diakui, dilindungi dan dijamin pelaksanaannya oleh hukum yang berlaku. Sementara itu, aparat penegak hukum merupakan pihak yang bertanggung jawab untuk memobilisasi atau melaksanakan hukum sebagaimana mestinya manakala terjadi perbuatan-perbuatan yang merugikan hak dan kepentingan seseorang sebagai subjek hukum.

Indonesia yang merupakan negara beranekaragam suku dan budaya dengan berbagai macam kekayaan budaya. Indonesia mempunyai hukum adat sebagai sebuah sistem hukum yang hidup turun temurun dari satu generasi ke generasi berikutnya yang masih coba dipertahankan dewasa ini ditengah terjangan sistem hukum nasional, yang tidak bisa dipungkiri merupakan cabang dari produk hukum kolonial terdahulu (KUHP dan KUHPer). Kekayaan budaya dan kearifan lokal tersebut mempunyai metode dan caranya tersendiri dalam penyelesaian masalah yang timbul dalam kehidupan bermassyarakat. Cara tersebut mempunyai tempat tersendiri dalam sistem peradilan di Indonesia.

Salah satu corak keanekaragaman budaya Indonesia adalah metode musyawarah mufakat dalam menyelesaikan sengketa yang timbul di kalangan masyarakat. Musyawarah mufakat merupakan metode yang digunakan hampir di semua kalangan masyrakat adat di Indonesia, salah satunya demi menemukan jalan dalam menyelesaikan perkara dengan jalan diplomasi dan kesamaan tujuan sebuah mesyarakat dalam suatu wilayah tertentu (pribumi). Namun dahulu dengan adanya proses introduksi dan perkembangan suatu sistem hukum asing yang dibawa masuk kedalam tatanan sistem hukum lokal Indonesia yang dibawa oleh pemerintah kolonial mulai menggerus metode masyarakat adat dalam meyelesaikan sengketa. Sistem hukum asing atau Eropa kontinental mulai dipaksakan penerapannya di hindia belanda (Indonesia), yang nota bene merupakan sistem hukum eropa yang berakar pada tradisi hukum indo-jerman dan romawi-kristiani, dan yang dimuktahirkan lewat berbagai revolusi mulai dari papal revolutions hingga revolusi kaum borjuis-liberal di Perancis pada akhir abad ke-19.

Dalam sistem peradilan pidana, Kitab undang-undang hukum pidana yang dikonkordansikan dari WVS terbitan pemerintah kolonial belanda masih di gunakan sampai saat ini. Hal ini sejalan dengan pidato Esmi Warassih dalam pidato pengukuhan beliau sebagai Guru besar, bahwa "Penerapan suatu sistem hukum yang tidak berasal atau ditumbuhkan dari kandungan masyarakat merupakan masalah, khususnya di negara-negara yang sedang berubah kerena terjadi ketidak cocokan antara nilai-nilai yang menjadi pendukung sistem hukum dari negara lain dengan nilai-nilai yang dihayati oleh anggota masyarakat itu sendiri". Pendapat ini juga sejalan dengan pendapat Von savigny yang menjelaskan bahwa terdapat hubungan organik antara hukum dan watak atau karakter suatubangsa, hukum hanyalah cerminan dari volgeist (jiwa bangsa) bangsa yang bersangkutan. Maka usaha pemerintah dalam melakukan pembaharuan hukum pidana dibidang substansinya melalui pembahruan KUHP dan KUHAP merupakan sebuah langkah penting dalam mewujudkan sejalannya hukum nasional dan perkembangan hukum dalam masyarakat, hal ini terlepas dari beberapa hal negatif yang timbul dalam proses pembentukan substansi hukum pidana umum diatas. 
Dewasa ini, ditengah kuatnya paham normatif-positivisme para hakim dan pembentuk Undang-undang Indonesia. Sebuah ide yang berakar dari kearifan lokal masyarakat adat yang coba menerapkan metode musyawarah mufakat dalam penyelesaian perkara pidana di Indonesia-pun muncul. Lebih jelasnya seiring berjalan waktu, perubahan dan dinamika masyarakat yang teramat kompleks di satu sisi sedangkan di sisi lain terhadap regulasi pembuatan peraturan- perundang-undangan sebagai kebijakan legislasi yang bersifat parsial ternyata sifat publik dari hukum pidana bergeser sifatnya karena relatif juga memasuki ranah privat dengan dikenal dan di praktekannya mediasi penal sebagai salah satu bentuk penyelesaian perkara di luar pengadilan.

Mediasi adalah merupakan salah satu bentuk penyelesaian perkara pidana diluar pengadilan yang lazim diterapkan dalam perkara perdata. Pada hukum positif Indonesia, asasnya perkara pidana tidak dapat diselesaikan diluar pengadilan, walaupun dalam hal-hal tertentu dimungkinkan. Namun selama ini implikasi praktek penyelesaian perkara pidana diluar pengadilan secara parsial berlandaskan kepada surat kapolri No: B/3022/XII/2009/SDEOPS tanggal 14 desember 2009 tentang penanganan kasus melalu alternative dispute resolutions (ADR). Tentu saja praktek mediasi penal yang merupakan salah satu implementasi dari Restorative Justice yang sudah coba diterapkan dalam penyelesaian perkara pidana tidak sejalan dengan sistem peradilan pidana indonesia yang kaku. Salah satu wujud implementasi Restorative Justice ialah melalui mediasi penal yang menurut Natangsa Subakti dipandang sebagai suatu pola penyelesaian perkara yang berakar dari budaya masyarakat tradisional, lalu kemudian dikemas dalam terminologi kontemporer. Eksistensi mediasi penal sebagai penyelesaian perkara pidana diluar pengadilan merupakan dimensi baru apabila dikaji dari segi teoritis.

Jika di hubungkan dengan Pancasila sebagai dasar ideologi negara, maka mediasi penal yang berbentuk musyawarah mufakat sejalan dengan sila ke 4 Pancasila yakni "Kerakyatan yang dipimpin oleh hikmah kebijaksanaan dalam permusyawaratan/perwakilan" yang secara bahasa menjelaskan bahwa Indonesia adalah sebuah negara demokrasi. Demokrasi pancasila yang menyerukan untuk pembuatan keputusan melalui musyawarah mencapai mufakat. Demokrasi Pancasila bermakna demokrasi berdasarkan kekuasaan rakyat yang diinspirasikan dan terintegrasi dengan prinsip-prinsip pancasila lainnya. Takdir Rahmadi dalam bukunya menjelaskan pengertian mediasi, menurut beliau mediasi adalah, suatu proses penyelesaian sengketa antara dua pihak atau lebih melalui perundingan atau cara mufakat dengan bantuan pihak netral yang tidak memiliki kewenangan memutus. Mediasi dalam praktek peradilan perdata telah diatur tersendiri diluar HIR/RBg yakni dalam PERMA nomor 1 tahun 2016 tentang prosedur mediasi di pengadilan dan juga dalam Undang-undang No. 30 Tahun 1999 tentang arbitrase dan alternatif penyelesaian sengketa. Sedangkan dalam praktek peradilan pidana, dikenal nama mediasi penal yang pada dasarnya mempunyai kesamaan sifat dan tujuan dengan mediasi dalam praktek peradilan perdata, yang berbeda adalah mediasi penal dikenal dalam praktek peradilan pidana.

Konsekuensi makin diterapkannya mediasi penal sebagai salah satu alternatif penyelesaian perkara dibidang hukum pidana melalui restitusi dalam proses pidana yang menunjukkan bahwa perbedaan antara hukum pidana dan perdata tidak begitu besar dan perbedaan itu menjadi tidak berfungsi.Pemikiran diatas sejalan dengan metode musyawarah mufakat dalam masyarakat adat Indonesia yang dalam penyelesaian perkara melalui musyawarah mufakat, tidak membedakan secara jelas antara permasalahan yang dalam bidang hukum privat atau permasalahan yang masuk dalam hukum publik, keduanya mempunyai bentuk dan metode penyelesaian musyawarah yang sama, yang berbeda hanyalah objek permasalahan.

Tentu saja tidak semua tindak pidana dapat diselesaikan melalui metode mediasi penal, hanya tindak pidana yang mempunyai ancaman pidana yang ringan sebagaimana yang disebutkan oleh Muzakkir dalam makalahnya bahwa salah satu kategorisasi tindak pidana yang dapat diselesaikan diluar pengadilan melalui metode Mediasi Penal adalah Tindak Pidana yang termasuk kategori ringan/serba ringan dan aparat penegak hukum menggunakan wewenangnya untuk melakukan diskresi. Salah satu tindak pidana yang umum terjadi di 
masyarakat adalah tindak pidana penggelapan yang diatur dalam kitab Undang-undang Hukum pidana. Tindak pidana penggelapan atau kejahatan terhadap harta benda secara umum diatur dalam BAB XXIV Kitab Undang-undang Hukum Pidana dalam Pasal 372 KUHP sampai dengan pasal 377 KUHP). Diantara beberapa pasal tersebut terdapat ancaman pidana yang ringan yang dapat dijatuhkan terhadap pelaku tindak pidana yang dapat diselesaikan melalui metode Restorative Justice seperti yang terdapat dalam pasal 373 KUHP bahwa : "Perbuatan yang dirumuskan dalam pasal 372 apabila yang digelapkan bukan ternak dan harganya tidak lebih dari dua puluh lima rupiah, diancam sebagai Penggelapan ringan dengan pidana penjara paling lama tiga bulan atau pidana denda paling banyak dua ratus lima puluh rupiah".

Bahwa berdasarkan nota kesepakatan bersama ketua mahkamah agung, menteri hukum dan hak azasi manusia, jaksa agung, kepala kepolisian Republik Indonesia, Pasal 373 KUHP merupakan salah satu tindak pidana ringan yang dapat diselesaikan menggunakan metode Restorative Justice. Seyogyanya tindak pidana penggelapan sebagaimana yang diatur dalam pasal tersebut diatas tidak perlu dilakukan penyelesaian melalui Pengadilan apabila jika melalui mediasi penal sudah tercapai tujuan pemidanaan. Selain itu mengurangi intensitas perkara yang masuk ke pengadilan melalui metode mediasi penal juga dapat memberikan ruang berfikir bagi hakim dalam menyelesaikan tindak pidana lainnya yang dianggap lebih berdampak besar bagi masyarakat semisal tindak pidana Korupsi. Salah satu azas yang dikenal umum dalam hukum acara adalah azas peradilan yang cepat, sederhana dan biaya ringan yang terdapat dalam Pasal 4 ayat (2) UU No. 4 tahun 2004.

Mediasi penal merupakan alternatif penyelesaian perkara pidana di luar jalur penal. Dalam penyelesaian perkara pidana jika menempuh jalur penal biasanya selalu adanya penjatuhan pidana oleh hakim terhadap pelaku, hal ini secara filosofis kadang-kadang tidak memuaskan semua pihak, oleh karena itu perlu adanya pemikiran penyelesaian perkara pidana melalui jalur ADR (alternative dispute resolution) dengan maksud agar dapat menyelesaikan konflik yang terjadi antara pelaku dengan korban. Pendekatan melalui jalur ADR, pada mulanya termasuk dalam wilayah hukum keperdataan, namun dalam perkembangannya dapat pula digunakan oleh hukum pidana, hal ini sebagaimana diatur dalam dokumen penunjang Kongres PBB ke-6 Tahun 1995 dalam Dokumen A/CO NF.169/6 menjelaskan dalam perkara-perkara pidana yang mengandung unsur fraud dan white-collar crime atau apabila terdakwanya korporasi, maka pengadilan seharusnya tidak menjatuhkan pidana, tetapi mencapai suatu hasil yang bermanfaat bagi kepentingan masyarakat secara menyeluruh dan mengurangi kemungkinan terjadinya pengulangan.

Menurut Muladi model konsensus yang dianggap menimbulkan konflik baru harus diganti dengan model asensus, karena dialog antara yang berselisih untuk menyelesaikan masalahnya, adalah langkah yang sangat positif. Dengan konsep ini muncul istilah ADR yang dalam hal-hal tertentu menurut Muladi lebih memenuhi tuntutan keadilan dan efesien. ADR ini merupakan bagian dari konsep restorative justice yang menempatkan peradilan pada posisi mediator. Untuk lebih jelasnya dapat dilihat dalam United Nations Office for Drug Control and Crime Prevention, dinyatakan bahwa restorative justice merupakan sebuah istilah baru terhadap konsep lama. Pendekatan restorative justice telah digunakan dalam memecahkan masalah konflik antara para pihak dan memulihkan perdamaian di masyarakat. Karena pendekatanpendekatan retributive atau rehabilitative terhadap kejahatan dalam tahun-tahun terakhir ini dianggap sudah tidak memuaskan lagi. Oleh karenanya menyebabkan dorongan untuk beralih kepada pendekatan restorative justice. Kerangka pendekatan restorative justice melibatkan pelaku, korban dan masyarakat dalam upaya untuk menciptakan keseimbangan, antara pelaku dan korban.

Juga dapat dilihat dalam Dokumen A/CONF.187/8 yang disampaikan pada kongres PBB ke-10 tentang the Prevention of crime and the Treatment of Offenders yang diselenggarakan di Vienna, 10 - 17 April 2000, yang mana pada bagian basic principles of justice for offenders and victims, antara dicantumkan mengenai the alternative of restorative justice. Menurut dokumen restorative justice dipandang sebagai sebuah model alternatif dalam peradilan pidana. Di mana semua pihak ambil bagian untuk menyelesaikan permasalahan tertentu secara bersama-sama bagaimana menghadapi akibat dari permasalahan itu serta implikasinya bagi yang akan datang. 
Dalam model ini, penekanannya terletak pada perbaikan (reparation) dan pencegahan (prevention) ketimbang menjatuhkan pidana. Restorative justice ini dan bentuk-bentuk lainnya dari penyelesaiain perselisihan (dispute resolusion) baik formal maupun semi formal, mencerminkan kecenderungan masa kini dari faham individualisme dan mengurangi fungsi dari negara.

Menurut Adam Graycar, Directur of Australian Institute of Criminologi, menyatakan bahwa dalam praktiknya restorative justice, memerlukan dukungan teori reintegrative shaming dalam menyelesaikan konflik. Graycar menjelaskan dengan mensitir pendapat Braithwaite mengenai teori reintegrative shaming, bahwa ada dua segi utama yang melekat pada proses restorative. Pertama untuk mencapai keberhasilan reintegrasi itu, maka proses yang dilakukan harus melibatkan kehadiran dan peran serta masyarakat bagi dukungan terhadap pelaku dan korban. Kedua adalah proses yang memerlukan adanya perasaan malu (shaming) sebagai pencelaan (confrontation) atas perbuatan salah antara pelaku dan korban. Proses melalui pendekatan restorative ini bertujuan: a) menjelaskan kepada pelaku bahwa perbuatan tersebut merupakan perbuatan yang tercela di masyarakat, b) dukungan dan menghargai seseorang walaupun perbuatannya tersebut merupakan perbuatan yang tercela. Dengan demikian, tujuan dari program restorative tersebut, ialah mengembalikan pelaku dan korban ke dalam masyarakat, agar mereka dapat menjadi anggota masyarakat yang bertanggung jawab, mematuhi hukum dan menjunjung tinggi nilai-nilai yang hidup dalam masyarakat.

Dengan pemikiran tersebut di atas perlu adanya pemikiran untuk menyelesaikan perkara pidana melalui jalur mediasi penal sebagai upaya untuk menyelesaikanh konfklik yang terjadi secara menyeluruh sehingga para pihak yang berpekara dapat menyelesaikan masalah dengan kesadaran sendiri dengan mengutama saling pengertian dan penghormatan kepada hak-hak korban.

\section{Hasil dan Pembahasan}

\subsection{Mediasi Penal Dalam Konstruksi Teori dan Hukum}

Dimensi ilmu hukum hakikatnya teramat luas. Diibaratkan sebuah "pohon", hukum adalah sebuah pohon besar dan rindang yang terdiri dari daun, akar, ranting, batang, buah yang teramat lebat. Karena begitu lebatnya hukum tersebut dapat dikaji dari perspektif asasnya, sumbernya, pembedaannya, penggolongannya dan lain sebagainya. Apabila dikaji dari perspektif penggolongannya hukum dapat diklasifikasikan berdasarkan sumbernya, bentuknya, isinya, tempat berlakunya, masa berlakunya, cara mempertahankannya, sifatnya, dan berdasarkan wujudnya.

Dikaji dari perspektif sejarahnya, hukum pidana yang bersifat hukum publik seperti dikenal sekarang ini telah melalui suatu perkembangan panjang. Perkembangan hukum pidana dipandang sebagai suatu tindakan merusak atau merugikan kepentingan orang lain dan disusuli suatu pembalasan. Pembalasan itu umumnya tidak hanya merupakan kewajiban seseorang yang dirugikan atau terkena tindakan melainkan meluas menjadi kewajiban seluruh keluarga, dan bahkan beberapa hal menjadi kewajiban masyarakat. Akan tetapi, seiring berjalannya waktu, perubahan dan dinamika masyarakat yang teramat kompleks di satu sisi, sedangkan disisi lainnya terhadap regulasi pembuatan peraturan perundang-undangan sebagai kebijakan legislasi yang bersifat parsial ternyata sifat publik hukum pidana bergeser sifatnya karena relatif juga memasuki ranah privat dengan dikenal dan dipraktekkan mediasi penal (penal mediation) sebagai sebuah bentuk penyelesaian perkara diluar pengadilan.

Dikaji dari perspektif terminologinya, mediasi penal dikenal dengan istilah mediation in criminal cases, mediation in penal matters, victim offenders mediation, offender victim arrangement (Inggris), strafbemiddeling (Belanda), der AuBergerichtliche Tatausgleich (Jerman), de mediation penale (Perancis ). Pada dasarnya, mediasi penal merupakan salah satu bentuk alternatif penyelesaian sengketa diluar pengadilan (Alternative Dispute Resolution/ADR) yang lazim diterapkan terhadap perkara perdata. Pada dimensi ini, ADR di luar pengadilan telah diatur dalam UU Nomor 30 Tahun 1999 tentang Arbitrase dan Alternatif Penyelesaian Sengketa. Dalam hubungan ini telah terdapat beberapa lembaga pendorong metode ADR, antara lain Badan Arbitrase Nasional Indonesia (BANI) yang memfokuskan pada 
dunia perdagangan dan ADR dalam penyelesaian sengketa jasa konstruksi (UU Nomor 18 Tahun 1999 jo UU Nomor 29 Tahun 2000 jo PP Nomor 29 Tahun 2000) dengan yurisdiksi bidang keperdataan. Begitu pula ADR dikenal juga menyangkut hak cipta dan karya intelektual, perburuhan, persaingan usaha, perlindungan konsumen, lingkungan hidup dan lain-lain.

Pada hukum positif Indonesia asasnya perkara pidana tidak dapat diselesaikan di luar pengadilan, walaupun dalam hal-hal tertentu dimungkinkan adanya penyelesaian kasus di luar pengadilan. Akan tetapi, praktik penegakan hukum di Indonesia sering juga perkara pidana diselesaikan di luar pengadilan melalui diskresi aparat penegak hukum, mekanisme perdamaian, lembaga adat dan lain sebagainya. Implikasi praktek penyelesaian perkara di luar pengadilan selama ini memang tidak ada landasan hukum formalnya, sehingga lazim juga terjadi suatu kasus secara informal telah dilakukan penyelesaian damai melalui mekanisme hukum adat, namun tetap saja diproses kepengadilan sesuai hukum positif yang berlaku. Konsekuensi makin diterapkan eksistensi mediasi penal sebagai salah satu alternatif penyelesaian perkara dibidang hukum pidana melalui restitusi dalam proses pidana menunjukkan, bahwa perbedaan antara hukum pidana dan perdata tidak begitu besar dan perbedaan itu menjadi tidak berfungsi.

Eksistensi mediasi penal merupakan dimensi baru dikaji dari aspek teoretis dan praktik. Seiring berjalannya waktu ketika semakin hari terjadi peningkatan jumlah volume perkara diselesaikan di pengadilan, maka polarisasi dan mekanisme m ediasi penal merupakan salah satu solusi menekan volume perkara, sepanjang hal tersebut sungguh-sungguh dikehendaki bersama para pihak (tersangka dan korban), serta untuk mencapai kepentingan yang lebih luas, yaitu terpeliharanya harmonisasi sosial. Mudzakkir mengemukakan kategorisasi ruang lingkup perkara yang dapat diselesaikan melalui mediasi penal adalah sebagai berikut :

1) Pelanggaran hukum pidana tersebut termasuk kategori delik aduan, baik aduan yang bersifat absolut maupun aduan yang bersifat relatif.

2) Pelanggaran hukum pidana tersebut memiliki pidana denda sebagai ancaman pidana dan pelanggar telah membayar denda tersebut (Pasal 80 KUHP).

3) Pelanggaran hukum pidana tersebut termasuk kategori "pelanggaran", bukan "kejahatan", yang hanya diancam dengan pidana denda.

4) Pelanggaran hukum pidana tersebut termasuk tindak pidana di bidang hukum administrasi yang menempatkan sanksi pidana sebagai ultimum remedium.

5) Pelanggaran hukum pidana tersebut termasuk kategori ringan/serba ringan dan aparat penegak hukum menggunakan wewenangnya untuk melakukan diskresi.

6) Pelanggaran hukum pidana biasa yang dihentikan atau tidak diproses ke pengadilan (deponir) oleh Jaksa Agung sesuai dengan wewenang hukum yang dimilikinya.

7) Pelanggaran hukum pidana tersebut termasuk kategori pelanggaran hukum pidana adat yang diselesaikan melalui lembaga adat . (Mudzakkir, 2007: 4) Tegasnya, aspek dan dimensi tersebut diselesaikan melalui dimensi kearifan lokal hukum adat. Melalui sejarah hukum dapat diketahui bahwa hukum yang mula pertama berlaku dan merupakan pencerminan kesadaran hukum rakyat Indonesia ialah kearifan lokal hukum adat.

Kemudian dikaji dari perspektif yuridis, mediasipenal dalam dimensi hukum negara (ius constitutum) sejatinya memang belum banyak dikenal dan masih menyisakan kontroversi, diantara pihak-pihak yang sepakat dan tidak sepakat untuk diterapkan. Persoalan esensialnya mengarah pada pilihan pola penyelesaian sengketa pidana, terkait domain superioritas negara dan superioritas masyarakat kearifan lokal. Selain dimensi diatas, implikasi lain sebenarnya eksistensi mediasi penal dapat dikatakan antara "ada" dan "tiada". Dikatakan demikian, di satu sisi oleh karena mediasi penal dalam ketentuan Undang-Undang tidak dikenal dalam SPP akan tetapi dalam tataran di bawah Undang-Undang dikenal secara terbatas melalui diskresi penegak hukum dan sifatnya parsial. Kemudian, di sisi lainnya ternyata praktik mediasi penal telah dilakukan oleh masyarakat Indonesia dan penyelesaian tersebut dilakukan di luar pengadilan seperti melalui mekanisme lembaga adat.

Dengan demikian, menjadi menarik selain dimensi di atas, eksistensi mediasi penal dapat dikaji dari perspektif filosofis, sosiologis, dan yuridis. Pada perspektif filosofis, mediasi penal diterapkannya asas "menang-menang" (win-win) dan bukan berakhir dengan situasi "kalah-kalah" (lost - lost) atau "menang - kalah" (win-lost) sebagaimana ingin dicapai oleh 
peradilan dengan pencapaian keadilan formal melalui proses hukum litigatif (law enforcement process). Melalui proses mediasi penal maka diperoleh puncak keadilan tertinggi karena terjadinya kesepakatan para pihak yang terlibat dalam perkara pidana tersebut yaitu antara pihak pelaku dan korban. Pihak korban maupun pelaku diharapkan dapat mencari dan mencapai solusi serta alternatif terbaik untuk menyelesaikan perkara tersebut. Implikasi dari pencapaian ini maka pihak pelaku dan korban dapat mengajukankom pensasi yang ditawarkan, disepakati dan dirundingkan antar mereka bersama sehingga solusi yang dicapai bersifat "menang- menang" (win-win). Selain itu, melalui mediasi penal ini akan mempunyai implikasi bersifat positif ketik a secara filosofis dicapainya peradilan dilakukansecaracepat,sederhana, danbiaya ringan karena pihak yang terlibat relatif lebih sedikit dibandingkan melalui proses peradilan dengan komponen Sistem Peradilan Pidana (SPP).

Dikaji dari perpektif sosiologis maka aspek ini berorientasi pada masyarakat Indonesia ketika akar budaya masyaratkannya berorientasi pada nilai budaya kekeluargaan, mengkedepankan asas musyawarah mufakat untuk menyelesaikan suatu sengketa dalam suatu sistem sosial. Tegasnya, aspek dan dimensi tersebut diselesaikan melalui dimensi kearifan lokal hukum adat. Melalui sejarah hukum dapat diketahui bahwa hukum yang mula pertama berlaku dan merupakan pencerminan kesadaran hukum rakyat Indonesia ialah kearifan lokal hukum adat.

Kemudian dikaji dari perspektif yuridis, mediasipenal dalam dimensi hukum negara (ius constitutum) sejatinya memang belum banyak dikenal dan masih menyisakan kontroversi, diantara pihak-pihak yang sepakat dan tidak sepakat untuk diterapkan. Persoalan esensialnya mengarah pada pilihan pola penyelesaian sengketa pidana, terkait domain superioritas negara dan superioritas masyarakat kearifan lokal. Selain dimensi diatas, implikasi lain sebenarnya eksistensi mediasi penal dapat dikatakan antara "ada" dan "tiada". Dikatakan demikian, di satu sisi oleh karena mediasi penal dalam ketentuan Undang-Undang tidak dikenal dalam SPP akan tetapi dalam tataran di bawah Undang-Undang dikenal secara terbatas melalui diskresi penegak hukum dan sifatnya parsial. Kemudian, di sisi lainnya ternyata praktik mediasi penal telah dilakukan oleh masyarakat Indonesia dan penyelesaian tersebut dilakukan di luar pengadilan seperti melalui mekanisme lembaga adat.

Eksistensi mediasi penal dapat dikaji dari perspektif filosofis, sosiologis, dan yuridis. Dikaji dari perpektif sosiologis aspek ini berorientasi pada masyarakat Indonesia yang akar budayanya berorientasi pada nilai budaya kekeluargan, mengkedepankan asas musyawarah mufakat untuk menyelesaikan suatu sengketa dalam suatu sistem sosial. Tegasnya, aspek dan dim ensi tersebut diselesaikan melalui dimensi kearifan lokal hukum adat. Melalui sejarah hukum dapat diketahui bahwa hukum yang mula pertama berlaku dan merupakan pencerminan kesadaran hukum rakyat Indonesia ialah kearifan lokal hukum adat. Aspek dan dimensi ini identik dengan theorie receptie dari Snouck Hurgronje. Untuk jangka masa yang cukup lama hukum adat sebagai suatu norma hukum, bersama-sama dengan norma- norma sosial lainnya dan norma agama Hindu, memainkan peranannya berfungsi sebagai alat pengendalian sosial.

Konsekuensi logis sebagai alat pengendalian sosial maka kearifan lokal hukum adat lahir, tumbuh, dan berkembang dalam suatu sistem sosial yang merupakan suatu sistem interaksi, jadi suatu tindakan manusia, yang melibatkan sejumlah individu. Sistem tindakan manusia itu, sebagai suatu sistem, tersusun atas jumlah bagian, yang disebut sub- sistem, yang saling berkaitan, dan saling mendukung. Tiap bagian atau sub sistem mempunyai fungsi tertentu terhadap sistem yang meliputinya. Talcott Parsons menyebut ada 4 (empat) fungsi yang meliputi, yaitu:

1) Fungsi adaptasi (Adaptation), yaitu penyesuaian diri terhadap situasi dan lingkungan. Fungsi ini menunjuk pada keharusan bagi sistem-sistem sosial untuk menghadapi lingkungannya;

2) Fungsi pencapaian tujuan (Goal attainment), yang merupakan pencapaian sasaran atau tujuan. Parsons beranggapan bahwa suatu tindakan diarahkan pada tujuannya. Namun perhatian yang diutamakan disini bukanlah tujuan pribadi individu, melainkan tujuan bersama para anggota dalam suatu sistem sosial; 
3) Fungsi integrasi (Integration) adalah memadukan atau mengakomodasikan pelbagai faktor yang terkait pada pencapaian tujuan. Yang terdiri atas penjaminan koordinasi yang perlu antara unit- unit dari sistem sosial berkaitan dengan kontribusi tiap unit pada organisasi dan berfungsinya secara keseluruhan;

4) Fungsi pemeliharaan pola atau latensi (patterns maintence atau latency) yaitu melestarikan pola- pola yang sudah terbentuk berdasarkan nilai-nilai.

Kearifan lokal hukum adat sebagai suatu model sosial dari Talcott Parsons titik beratnya pada fungsi integrasi. H.R. Otje Salman lebih lanjut menyebutkan hukum diarahkan untuk mengakomodasikan keseluruhan sistem sosial kemasyarakatan. Fungsi ini meliputi sistem kaidah (sistem norma) yang bertugas untuk mengoreksi perilaku menyimpang dari kaidahkaidah bersangkutan. Jadi kaedah-kaedah itu dalam integrasi sosial menuntut perilaku tertentu yang mewujudkan peranan-peranan tertentu. Dengan demikian, kaidah-kaidah ini merupakan kerangka orientasi perilaku manusia (anggota sistem kemasyarakatan).

Kearifan lokal hukum adat, menurut pandangan Soepomo diartikan sebagai "suatu hukum yang hidup, karena ia menjelmakan perasaan hukum yang nyata dari rakyat, serta hukum adat bersifat dinamis dan akan tumbuh serta berkembang sejalan dengan perkembangan masyarakatnya". Temuan Soepomo tersebut bertitik tolak dari konsepsi pemikiran Friedrich Carl von Savigny dengan madzab sejarah dan kebudayaan dari van Vollenhoven. Oleh sebab itu, hukum adat bersifat dinamis dan akan tumbuh serta berkembang sejalan dengan perkembangan masyarakatnya. Dalam bahasa Friedrich Carl von Savigny, hal tersebut disebut Volksgeist (jiwa bangsa). Volksgeist berbeda-beda menurut tempat dan zaman yang dinyatakan dalam bahasa adat-istiadat dan organisasi sosial rakyat.

Hampir identik dengan pendapat tersebut maka penggagas sosiologi hukum (sosiology of law) Eugene Ehrlich mengatakan bahwa, "The centre of gravity of legal development lies not ini legislation nor in juristic science, nor in judicial decision, but in society it self". Eugene Ehrlich mengganti term voksgeist Savigny dengan term yang khusus dan lebih rasional yaitu fakta-fakta hukum (Rechtstaatsachen/ fact of law) dan hukum yang hidup di dalam masyaraat (living law of the people).

Dimensi kearifan lokal hukum adat yang berlandaskan alam pikiran kosmis, magis dan religius ini berkorelasi aspek sosiologis dari cara pandang dan budaya masyarakat Indonesia. Dalam praktek sosial masyarakat Indonesia, lembaga mediasi penal sudah lama dikenal dan telah menjadi tradisi antara lain pada Masyarakat Papua, Aceh, Bali, Lombok, Sumatera Barat dan hukum adat Lampung. Selain itu, sebagai perbandingan maka mediasi penal di tingkat internasional telah lama dikenal. Dalam beberapa konferensi misalnya Konggres PBB ke-9 tahun 1995 khususnya yang berkorelasi dengan manajemen peradilan pidana (dokumen A/CONF 169/6) disebutkan perlunya semua negara mempertimbangkan "privatizing some law enforcement and justice functions" dan "alternative dispute resolution/ADR) berupa mediasi, konsiliasi, restitusi dan kompensasi dalam sistem peradilan pidana.

Kemudian dalam Konferensi Internasional Pembaharuan Hukum Pidana (International Penal Reform Conference) tahun 1999 dikemukakan bahwa salah satu unsur kunci dari agenda baru pembaharuan hukum pidana (the key elements of a new agenda for penal reform) adalah perlunya memperkaya sistem peradilan formal dengan sistem atau mekanisme informal dengan standar-standar hak asasi manusia (the need to enrich the formal judicial system with informal, locally based, dispute resolution mechanisms which meet human rights standards) yang mengindentifikasikan sembilan strategi pengembangan dalam melakukan pembaharuan hukum pidana melalui pengembangan restorative justice, alternative dispute resolution, informal justice, alternatives to custody, alternative ways of dealing with juveniles, dealing with violent crime, reducing the prison population, the proper management of prisons dan the role of civil in penal reform.

Begitu pula dalam Konggres PBB ke-10 tahun 2000 (dokumen A/CONF. 187/4/Rev.3), antara lain dikemukakan bahwa untuk memberikan perlindungan kepada korban kejahatan, hendaknya diintrodusir mekanisme mediasi dan peradilan restorative (restorative justice). Kemudian, sebagai tindak lanjut pertemuan internasional tersebut mendorong munculnya dokumen internasional yang berkorelasi dengan peradilan restoratif dan mediasi dalam perkara 
pidana berupa the Recommendation of the Council of Eure 1999 No. R (99) 19 tentang "Mediation in Penal Mattres", berikutnya the EU Framework Decision 2001 tentang "the Stannding of Victim in Criminal Proceedings" dan The UN Principles 2002 (Resolusi Ecosoc 2002/12) tentang "Basic Principles on the Use Restorative Justice Programmes in Criminal Matters". Kemudian, mediasi penal ini juga dikenal dalam beberapa Undang-Undang pada Negara Austria, Jerman, Belgia, Perancis dan Polandia.

Dari pelbagai ketentuan dipelbagai negara dapat disebutkan mediasi penal dimungkinkan dalam perkara pidana dan diberikan kerangka hukum (mediation within the framework of criminal law). Tony Peters mengemukakan gambaran pengaturan atau "legal framework" dibeberapa negara Eropa sebagai berikut.

1) Ditempatkan sebagai bagian dari UU Peradilan Anak (the Juvenile Justice Act), yaitu di Austria, Jerman, Finlandia, dan Polandia. Ditempatkan dalam KUHAP (the Code of Criminal Procedure), yaitu di Austria, Belgia, Finlandia, Perancis, dan Polandia.

2) Ditempatkan dalam KUHP (the Criminal Code), yaiu di Finlandia, Jerman, dan Polandia.

3) Diatur tersendiri secara otonom dalam UU Mediasi (the Mediation Act), seperti di Norwegia, yang diberlakukan untuk anak- anak maupun orang dewasa.

Pada awal penyelesaian perkara diluar pengadilan dikenal dengan istilah ADR yang merupakan bagian dari restorative justice yang merupakan kecenderungan baru dalam upaya menyelesaikan konflik antara pelaku dan korban atau para pihak yang berselisih. Kecenderungan orang menyelesaikan konflik dengan ADR dikarenakan banyak terjadinya penyelesaian kasus melalui peradilan tidak mencapai sasaran dan berkeadilan. Hal ini sebagaimana dijelaskan oleh Jacqueline M. Nolan-Haley, bahwa munculnya berhubungan dengan gerakan pembaharuan hukum di awal 1970-an, waktu itu banyak pengamat hukum dan masyarakat akademik mulai menaruh perhatian yang serius terhadap pengaruh negatif jalan proses peradilan.

Di mana upaya menuntut hak melalui jalur hukum, harus dilalui dengan jalan yang panjang dan berliku, biaya tinggi, hal ini sudah merupakan pemandangan yang umum dan biasa bagi masyarakat Amerika. Kondisi demikian menyebabkan orang mulai mencari alternatif lain sebagai upaya untuk menembus tersumbatnya proses peradilan tersebut. Untuk itu pada tahun 1976 telah diadakan berbagai diskusi sebagai suatu gerakan ke arah terbentuknya ADR. Sehingga pada tahun itu juga American Bar Association secara resmi mengakui gerakan ADR. Dengan mendirikan Special Committee on Minor Dispute yang kemudian menjadi Special Committee on Dispute Resolution. Sejumlah asosiasi dan pengacara di negara-negara bagian, juga telah mempunyai ADR Committee. Juga fakultas hukum (law schools) secara bertahap telah memasukkan ADR ke dalam kurikulum.

Dengan begitu pesatnya perkembangan ADR di Amerika, maka telah terjadi pergeseran pengertian ADR menjadi DR, dengan sendiri kata alternatif hilang dan seolah-olah penyelesaian sengketa hanya dapat dilakukan di luar pengadilan, padahal perubahan ini merupakan kritikan terhadap pengadilan yang seolah-olah ADR hanya merupakan alternatif dari kegagalan pengadilan. Hal ini sebagaimana dijelaskan oleh Mas Achmad Santoso, bahwa: penggantian istilah ADR menjadi DR, didasarkan atas pertimbagan psikologis, yaitu dalam upaya untuk mendapatkan dukungan dari kalangan pengadilan (bukan sebaliknya menentang pengadilan). Sebab dengan istilah ADR terkesan, bahwa ADR merupakan jawaban atas kegagalan pengadilan dalam memberikan akses masyarakat pada keadilan, sehingga permasyarakatan istilah ADR mengundang rasa tidak aman dan kecemburuan bagi insan pengadilan, sehingga penggunaan istilah ADR dianggap tidak taktis bagi upaya permasyarakatan dan pencarian dukungan dari berbagai kalangan.

Dengan begitu pesatnya perkembangan ADR menjadi DR, ini merupakan fenomena sosial yang sesuai dengan dokumen A/CO NF.169/6 di atas, yang menempatkan konsep ini dalam hukum pidana, namun tetap memberikan peran kepada pengadilan untuk turut menyelesaikan perkara pidana secara berkeadilan yang rasional berdasarkan prinsip Win-Win Solution dan bukan Win-Lose solution.

Fenomena penyelesaian perkara pidana melalui jalur ADR/DR yang menuju kepada Win-Win solution di Amerika, secara filosofis diadopsi untuk menyelesaikan perkara tindak pidana yang 
dilakukan korporasi, mengingat korporasi mempunyai organ yang kualitas dan dana. Jadi kemungkinan untuk memberikan dispensasi kepada korban dapat terwujud dengan prinsip Win-win solution yang rasional.

Menurut Covey penyelesaian secara Win-win solution atau menang-menang, dapat memuaskan semua pihak yang berpekara sama- sama untung, karena secara filosofisnya adalah: menang-menang berarti mengerti, bahwa kita hidup dalam suatu dunia yang saling tergantung, dan karenanya harus bekerjasama di dalamnya. Hal mana berarti bahwa dalam sebagian besar bidang kehidupan, kita harus bekerjasama dengan orang lain untuk mencapai sukses. Bila kita mengerti adanya saling ketergantungan termaksud, kita akan rela mengabdikan diri untuk bekerjasama dengan orang lain lewat cara-cara yang menjamin keberhasilan bersama, serta memungkinkan semua orang menjadi pemenang. Itulah hakikat dari sikap menang-menang. Ia akan memperlancar interaksi kita dengan sesama, dan akan menghasilkan kesepakatan serta pemecahan masalah yang memungkinkan semua pihak memperoleh apa yang diinginkan.

Lebih jelas lagi Covey mengatakan bahwa: Menang-menang, adalah suatu kerangka berpikir dan perasaan yang senantiasa mencari manfaat bersama dalam segala interaksi antar manusia. Menang-menang, berarti semua orang untung, karena kesepakatan atau pemecahan masalahnya menguntungkan dan memuaskan kedua belah pihak. Dengan pemecahan yang menang-menang, semua pihak merasa senang terhadap keputusan yang diambil serta terikat untuk ikut melaksanakan rencana tindakan yang telah disepakati.

Prinsip Menang-Menang ini menurut pemikiran penulis cocok untuk di adopsi sebagai salah satu alternatif penyelesaian perkara tindak pidana yang dilakukan korporasi/orang, mengingat dalam konsep rancangan KUHP (baru) bahwa salah tujuan dari pemidanaan adalah untuk menyelesaikan konflik yang ditimbulkan oleh tindak pidana, memulihkan keseimbangan, dan mendatangkan rasa damai dalam masyarakat; dan membebaskan rasa bersalah pada terpidana. Hal ini sebagaimana diatur pada Pasal 50 ayat 1 sub c dan d konsep rancangan KUHP (baru) tahun 1999-2000.

Berdasarkan pemikiran tersebut di atas, perlu dikembangkan tentang prinsip yang terkandung dalam penyelesaian perkara di luar pengadilan yaitu:

1) Perlu Adanya Seorang Mediator Dalam Penanganan Konflik.

Dalam hal ini mediator harus dapat menyakinkan mereka yang terlibat konflik dengan mengedepankan proses komunikasi. Dalam komunikasi bahwa kejahatan jika dibiarkan akan menimbulkan konflik interpersonal malahan kadang meluas menjadi konflik massa, untuk mediator harus mampu menjelaskan penting mediasi dalam rangka untuk menghilangkan rasa sakit hati dan berupaya mengembalikan bahwa kejadian-kejadian tersebut merupakan kekeliruan yang harus diperbaikan dengan dasar saling pengertian.

2) Mengutamakan Kualitas Proses

Dalam melakukan mediasi yang dicari adalah kualitas proses bukan hasil untuk menentukan yang kalah dan menang, di sini dalam proses perlu adanya kesadaran dari masing-masing pihak untuk saling menghargai hingga tercapai penyelesaian win-win solution.

3) Proses Mediasi Bersifat Informal

Dalam mediasi diupayakan menghindari adanya pembicaraan yang bersifat formal, sehingga para pihak yang terlibat merasa saling di hargai.

4) Upayakan Semua Terlibat Dalam Proses Mediasi

Dalam mediasi semua harus ditanam rasa tanggung jawab tentang hasil yang akan dicapai dalam melakukan mediasi penal. Dalam pelibatan semua pihak ditanam budaya malu dan budaya saling memaafkan dengan tujuan jika proses mediasi telah berhasil semua pihak tidak merasa dipermalukan.

\subsection{Mediasi Penal Dalam Sistem Peradilan Pidana}

Pemikiran yang mengedepankan penyelesaian perkara pidana di luar pengadilan sebagaimana yang terjadi di Amerika, lambat laun dapat berimbas ke Indonesia mengingat opini dan pandangan para praktisi hukum dan akademisi terhadap proses peradilan pidana sangatlah 
mengecewakan dan menyedihkan bagi para pencari keadilan. Untuk itu fenomena penyelesaian di luar pengadilan perlu dicermati para penegak hukum Indonesia yang saat sekarang berada dalam posisi yang sangat nadir dan mencemaskan bagi penegakkan hukum secara normatif. Hanya saja perlu juga dipikirkan bahwa penyelesaian perkara di luar pengadilan jangan menimbulkan persoalan-persoalan hukum baru, terutama terhadap lembaga peradilan yang tidak mempunyai fungsi sama sekali. Dalam konteks demikian jika dimungkinkan adanya jalur penyelesaian hukum di luar pengadilan, hanya merupakan penyeimbang dari kebijakan penal dan merupakan alternatif kebijakan non penal.

Untuk itu perlu adanya terobosan dalam sistem peradilan pidana untuk mengupayakan adanya mediasi penal. Adapun latar belakang pemikirannya ada yang dikaitkan dengan ide-ide pembaharuan hukum pidana (penal reform), dan ada yang dikaitkan dengan masalah pragmatisme. Latar belakang ide-ide "penal reform" itu antara lain ide perlindungan korban, ide harmonisasi, ide restorative justice, ide mengatasi kekakuan/formalitas dalam sistem yang berlaku, ide menghindari efek negatif dari sistem peradilan pidana dan sistem pemidanaan yang ada saat ini, khususnya dalam mencari alternatif lain dari pidana penjara (alternative to imprisonment/alter-native to custody) dsb. Latar belakang pragmatisme antara lain untuk mengurangi stagnasi atau penumpukan perkara ("the problems of court case overload"), untuk penyederhanaan proses peradilan dsb.

Pemikiran tersebut di atas sebagai kerangka teoriktik, juga kearifan lokal dalam hukum adat di Indonesia yang berlandaskan alam pikiran kosmis, magis dan religius sudah lama mengenal lembaga mediasi penal ini, antara lain di Sumatera Barat, Aceh, dan hukum adat Lampung. Bahkan di Aceh (NAD) sudah dituangkan dalam Perda No. 7/2000 tentang Penyelenggaraan Kehidupan Adat yang antara lain intinya mengatur sbb: Pasal 13: sengketa diselesaikan terlebih dahulu secara damai melalui musyawarah adat. Pasal 14: perdamaian: mengikat para pihak; yang tidak mengindahkan keputusan adat, dikenakan sanksi adat. Pasal 15: apabila para pihak tidak puas terhadap putusan adat dapat mengajukan perkaranya ke aparat penegak hukum.

Keputusan adat dapat dijadikan pertimbangan oleh aparat penegak hukum. Dalam praktek peradilan pidana di Indonesia pun pernah terjadi (dalam kasus Ny. Ellya Dado, disingkat "Kasus Ny. Elda"), adanya "perdamaian" digunakan sebagai pertimbangan untuk menyatakan bahwa tindak pidana yang terbukti tidak lagi merupakan suatu kejahatan ataupun pelanggaran, dan oleh karenanya melepaskan tertuduh dari segala tuntutan hukum. Dalam rangcangan Kitab Undang-Undang Hukum Acara Pidana tentang Mediasi Penal diatur pada Pasal 111:

(1) Penyidik berwenang menghentikan penyidikan karena tidak terdapat cukup bukti atau peristiwa tersebut ternyata bukan merupakan tindak pidana atau penyidikan dihentikan demi hukum.

(2) Penghentian penyidikan sebagaimana dimaksud pada ayat (1) dapat juga dilakukan atas dasar: a. putusan hakim praperadian atas dasar permintaan korban/pelapor; b. dicapainya penyelesaian mediasi antara korban/pelapor dengan tersangka.

(3) Tindak pidana yang dapat diselesaikan melalui mediasi sebagaimana dimaksud pada ayat (2) huruf b terdiri atas: a. tindak pidana yang dilakukan bersifat ringan; e. tindak pidana yang dilakukan diancam dengan pidana penjara paling lama 4 (empat tahun); f. tindak pidana yang dilakukan hanya diancam dengan pidana denda; d. umur tersangka pada waktu melakukan tindak pidana di atas 70 (tujuh puluh) tahun; e. kerugiansudahdiganti;

(4) ketentuan sebagaimana dimaksud pada ayat (3) huruf d dan huruf e hanya berlaku untuk tindak pidana yang diancam dengan pidana penjara paling lama 5 (lima) tahun;

(5) Dalam hal penyidik menghentikan penyidikan sebagaimana dimaksud pada ayat (3), penyidik wajib menyampaikan laporan pertanggungjawaban kepada atasan penyidik.

(6) Ketentuan lebih lanjut mengenai tata cara penyelesaian melalui mediasi sebagaimana dimaksud pada ayat (3) diatur dengan Peraturan Pemerintah.

Rancangan KUHAP tersebut di atas dimungkinkan adanya mediasi penal pada tingkat penyidikan sebagai alasan penyidik menghentikan suatu perkara pidana dan juga diatur secara limitatif tentang tindak pidana bagaimanakah yang dapat dilakukan mediasi. Persoalan yang 
muncul bagaimana jika ditingkat penyidikan para pihak tidak melakukan mediasi penal, tetapi kesadaran itu muncul pada tingkat penuntutan atau pada sidang pengadilan apakah mediasi penal dapat dilakukan?.

Menurut pemikiran bahwa mediasi dapat saja dilakukan pada tingkat penuntutan maupun pada sidang pengadilan dengan pertimbangan kepastian hukum, kemanfaatan hukum dan keadilan hukum dengan argumentasi adalah jika mediasi penal dilakukan pada tingkat penuntutan, asas yang dapat digunakan adalah asas oportunitas yang merupakan ajaran yang memberikan kewenangan kepada Jaksa untuk mengenyampingkan perkara, walaupun telah cukup bukti-buktinya, demi kepentingan umum baik dengan syarat maupun tanpa syarat. Asas oportunitas secara normatif diatur padal Pasal 35 huruf c Undang-undang Nomor 16 tahun 2004 tentang Kejaksaan Republik Indonesia dengan rumusan; Jaksa Agung mempunyai tugas dan wewenang mengesampingkan perkara demi kepentingan umum, yang terkenal dengan sebutan seponering. Sedangkan pada sidang pengadilan mediasi penal dimungkinkan dapat dilakukan dengan pertimbangan para pihak benar-benar menyadari pentingnya menyelesaikan konflik melalui musyawarah dengan kesadaran akan manfaat dari perdamaian dan saling memaafkan, ini pernah dilakukan oleh Hakim Bismar Siregar.

\section{Simpulan dan saran}

Berdasarkan uraian dan pemikiran pada pembahasan tersebut di atas, maka dapat disimpulkan beberapa hal. Pertama, mediasi penal dapat dilakukan jika para pihak yang terlibat dalam perudingan saling menyadari dan menghargai terhadap hasil yang diperoleh dalam mediasi penal, karena prinsip yang terpenting dalam mediasi penal adanya pengakuan kesalahan dan pemberian maaf oleh pihak yang dirugikan akibat tindak pidana untuk mencapai penyelesaian berupa win-win solution. Kedua, dalam sistem peradilan pidana baik pada tingkat penyidikan, penuntutan maupun sidang pengadilan dimungkinkan adanya mediasi penal dengan berpegang pada prisip kepastian hukum, kemanfaatan hukum dan keadilan hukum.

\section{Daftar Rujukan}

Arief, Barda Nawawi. 2008. Mediasi Penal Penyelesaian Perkara Diluar Pengadilan. Semarang: Pustaka Magister.

Arief, Barda Nawawi. 2008. Kebijakan Legislatif dalam Penanggulangan Kejahatan dengan Pidana Penjara, BP UNDIP. Semarang, cetakan ke-3, 2000.

Arief, Barda Nawawi. 2008. Pemberdayaan Court Management Dalam Rangka Meningkatkan Fungsi Mahkamah Agung (Kajian dari Aspek system Peradilan Pidana). Makalah Pada Seminar Nasional Pemberdayaan Court Manajement di Mahkamah Agung R.I., dan diskusi Buku Fungsi Mahkamah Agung, F.H., UKSW, salatiga, I Maret 2001.

Covey. 1994. The Seven Habits of Highly Effecive People (terjemahan). Covey Leadership Center. Curzon, L.B. 1979. Jurisprudence. Macdonald \& Evans Ltd, Playmouth.

Hadikusuma, Hilman. 1979. Hukum Pidana Adat. Bandung: Alumni; dan Natangsa Surbakti, Gagasan Lembaga Pemberian Maaf Dalam Konteks Kebijakan Pembaharuan Sistem Peradilan Pidana di Indonesia, Tesis S2 Hukum UNDIP, 2003.

Haley, M. Nolan. 1992. Alternative Dispute Resolution. West Publishing C., St. Paul. Hamzah, Andi. Terminologi Hukum Pidana. Jakarta: Penerbit: Sinar Grafika.

Johson, Doyle P. 1985. Teori Sosiologi Klasik dan Modern. Jakarta: PT Gramedia.

Eugene, Ehrlich. 1936. Fundamental Principles of the Sociology of Law. New York.

Muladi. 1995. Kapita Selekta Sistem Peradilan Pidana. Semarang: Badan Penerbit Universitas Diponegoro.

Muladi. 1997. Hak Asasi Manusia, Politik dan Sistem Peradilan Pidana, Semarang: Badan Penerbit Universitas Diponegoro.

Mulyadi, Lilik. 2012. Bunga Rampai Hukum Pidana Umum dan Khusus. Bandung: PT Alumni.

Mulyadi, Lilik. 2015. Mediasi Penal Dalam Sistem Peradilan Pidana Indonesia. Bandung: Alumni.

Pembukaan Undang-Undang Dasar 1945 Hasil Amandemen.

Putusan Pengadilan Negeri Jakarta Utara-Timur, No. 46/PID/78/UT/ WANITA, 17 Juni 1978. Hakim ketua sidang : Bismar Siregar, SH. 
Rahardjo, Satjipto. 2010. Masalah Penegakan Hukum. Yogyakarta: Genta Publishing.

Salman, H.R. Otje. 2007. Kesadaran Hukum Masyarakat Terhadap Hukum Waris. Bandung: PT Alumni.

Santoso, Mas Achmad. 1999. Perkembangan Lembaga ADR di Indonesia, Materi Pelatihan tentang Pilihan Penyelesaian Sengketa (Alternative Dispute Resolution/ADR) di Bidang Lingkungan. Kerjasama PPLH Lemlit UNDIP, ICEL, Asia Foundation dan Depkeh, Semarang, 10-13 April 1999.

Soekanto, Soerjono. 2010. Faktor-Faktor Yang Mempengaruhi Penegakan Hukum. Yogyakarta: Genta Publishing.

Suparman, Eman 2009. Hukum Perselisihan: Konflik Kompetensi dan Pluralisme Hukum Orang Pribumi. Bandung: Refika aditama.

Surbakti, Natangsa. 2011. Mediasi Penal Sebagai Terobosan Alternative Perlindungan Hak Korban Tindak Pidana. Jurnal Ilmu Hukum, 14.

Tanya, Bernard L, Yoan N Simanjuntak dan Markus Y Hage. 2006. Teori Hukum: Strategi Tertib Manusia Lintas Ruang dan Generasi. Surabaya: Cv kita.

United Nations Office For Drug Control and Crime Prevention. 1999. Handbook on Justice for Victims. Centre for International Crime Prevention, New York. 